\title{
Optimizing Income Tax and Value Added Tax on E-Commerce Transaction
}

\author{
I Nyoman Darmayasa $^{1}$, Murtiani Kumontoy ${ }^{2}$ \\ \{nyomandarmayasa@pnb.ac.id'1, murtiani.mk@gmail.com² \\ Accounting Department, Politeknik Negeri Bali, Badung, Indonesia ${ }^{1,2}$
}

\begin{abstract}
Indonesia has had declining tax revenue for the past two years. This research aimed to analyze how to optimize income tax and VAT on e-commerce transactions. This research was a qualitative and literature study review. Data came from international tax regulation practices on e-commerce transactions. Findings confirmed that tax imposition on e-commerce and conventional transactions were similar. It is necessary to create legal certainty and comprehensive tax regulation on e-commerce transactions. The government needs to evaluate taxable e-commerce transactions as an embodiment of fair regulation. This research provides a theoretical contribution for taxation on ecommerce transactions to increase tax basis.
\end{abstract}

Keywords: E-Commerce Transaction; Income Tax; Tax Basis, Value Added Tax

\section{Introduction}

The global economy is currently declining due to the coronavirus (Covid-19) [1] However, global economy digitization continues to improve. There were 202.6 million Indonesian internet users in January 2021 and 16\% (27 million internet users) growth compared to 2020. The total Indonesian internet penetration was 73.7\% in January 2021 [2]. Online communication offers various opportunities in the digital sector, such as e-commerce [3]. E-commerce became increasingly popular in global commerce. E-commerce started in 1995 as maintaining company transactions requires digital goods [4]. E-commerce or electric commerce refers to buying and selling using electronic means, especially through the internet [5]. [6] stated that e-commerce was one crucial strategy since it increases the efficiency rate of company operation. Therefore, e-commerce is the process of capital movement at the global level. Furthermore, e-commerce contributes to national and international economic development [7]. E-commerce and the internet may become instruments to encourage development and a sustainable economy [8]. Based on Sirclo.com [9] Indonesia is the biggest e-commerce market in the South East Asia region. About $90 \%$ of Indonesian internet users have accessed e-commerce. Online commerce activity increases capitalization value. Indonesian market capitalization reached IDR 294 billion in 2019. Furthermore, Indonesia may reach 221 million e-commerce users in 2025 [10]. E-commerce has a crucial role and significantly influences state and tax revenue [11]. Therefore, e-commerce transaction is an opportunity and challenge to tax imposition [12]. The government could not determine the 
Permanent Establishment (PE) of e-commerce businesses as opposed to conventional business. The government imposes a tax on international conventional businesses located abroad but having Indonesian PE. However, e-commerce companies do not require PE as their business operation uses an internet system. The majority of Indonesian e-commerce is subject to foreign tax and may operate in Indonesia freely. There is no consensus in determining countries with rights to impose a tax on e-commerce transactions. Due to the easiness of ecommerce, the government encounters difficulty in determining parties involved in ecommerce transactions. In addition, online banking and electronic payment system provide an easy payment system. The government could not detect or measure the revenue of domestic companies or individuals through a foreign bank, and therefore influence tax compliance. Tax authorities encounter difficulty in measuring tax compliance due to electronic payment and transactions [13]. A clear policy of tax imposition on e-commerce is necessary. The Indonesian government find it challenging to formulatie taxation policies on e-commerce transaction. The Indonesian government should formulate a policy that covers all tax potential over e-commerce transactions [14].

The Indonesian government issued a Government Regulation in Lieu of Law Number 1 of 2020 to increase state revenue due to the declining economy. During the covid-19 pandemic, only Electronic Systems Trading (EST) may grow and prevail. The Government Regulation in Lieu of Law Number 1 of 2020 Article 4, Article 6, and Article 7 regulate EST. Government Regulation in lieu of Law was amended into Law Number 02 of 2020 . Indonesia now has regulations regarding tax imposition on digital economic activities. The government issued a derivative rule to cover the budget deficit due to the government-provided stimulus in May 2020. The Minister of Finance Regulation of 48/PMK.03/2020 regulate tax collection on e-commerce of foreign companies operating in Indonesia. Due to the regulation of Minister of Finance Regulation 48/PMK.03/2020, the government determines foreign companies as the subject of Value Added Tax (VAT). This research aimed to analyze how to optimize the imposition of Income Tax and VAT on e-commerce transactions.

\section{Methods}

We conducted qualitative research to optimize the tax imposition on income tax and VAT of e-commerce transactions. Qualitative research produces descriptive data in the form of narratives or discourses [18]. The qualitative research uses a literature study approach by reviewing international and national tax regulations on e-commerce transactions. Literature study is qualitative research that focuses on one object to uncover the reality behind the phenomenon [19]. Literature study refers to studying various literature, regulations, books, articles, and previous similar studies to get a theoretical basis. Researchers collect data using documentation techniques by browsing various internationally reputed journals, accredited national journals, other scientific publications, minister of finance regulations, government regulations, and tax laws related to the research topic. Researchers assemble journals and regulations from the documentation process, assuming that the definition of documentation was the process of collecting facts and data from past documents [20]. In addition to scientific references, researchers collect data from documents and notes related to the research problem. We performed a literature study, discussion, and in-depth comprehension of tax regulations to formulate effective data analysis techniques. 


\section{Findings and Discussion}

\subsection{The History of E-Commerce}

E-commerce has become a crucial part of the community. Furthermore, World Wide Web has a major role in daily activities. E-commerce enables online and internet-based business [21]. E-commerce, in a broad sense, refers to business transactions using networks or computers. E-commerce refers to goods and services trade through the internet [22]. According to Gupta [23], e-commerce is related to trade through the internet. Each transaction involves the transfer of ownership or rights to use goods or services over a computer-mediated network. E-commerce is the process of selling and buying from one company to another using a computer. E-commerce gained popularity in the global economy on 1995, as retaining company transaction require digital goods. Digital goods are anything that can be sent over a digital network [24]. E-commerce is online or internet-based shopping that uses digital money transfer as the transaction medium between buyer and seller.

\subsection{E-commerce Diversification}

Laudon \& Traver [25] divide e-commerce into six classifications, namely: (1) Business to Consumer (B2C) e-commerce reaches individual consumers, (2) Business-to-Business (B2B) e-commerce connects one company to another, (3) Consumer-to-Consumer (C2C) enables consumers to interact with other consumers (individuals and companies), (4) Mobile ecommerce (m-commerce) refers to the use of mobile devices with cellular or wireless networks, (5) Social e-commerce uses social networks and social media, and (6) Local ecommerce focuses on engaging consumers based on geographic location. Business to Business (B2B) and Business to Customers (B2C) are the most widely used e-commerce in Indonesia. According to SE-62/PJ/2013, e-commerce is divided into four. First, Online Marketplace provides a place for buyers and sellers to conduct the transaction. The online marketplace is often called Online Shop or Online Mall). Second, Classified Ads provide a place and/or time to display the content of goods and services. Classified Ads is aimed at advertisement users through provided sites. Third, Daily Deals refer to business activity using vouchers as a payment medium. Fourth, Online Retail refers to goods and/or services transactions between Online Retail organizers and Online Retail users.

\subsection{Lex Specialist derogate Lex Generalist}

Lex Specialist derogate Lex Generalist is one of the important principles in legislation, meaning that special regulation (specialist) overrides general regulation (generalist). Based on this principle, general rules are no longer the legal basis due to special regulations. In other words, the special regulation will apply and have binding power in concrete events.

This principle is applied in taxation law. The government applied various domestic policies on foreign digital transaction income tax. Several domestic tax regulations target foreign digital potential such as the Circular of the Directorate General of Taxes number SE04/PJ/2017 on February 6, 2017, concerning Determination of PE for Foreign Tax Subjects Providing Application Services and/or Content Services via the Internet. The government reimplemented the Regulation of the Minister of Finance Number 35/PMK.03/2019 regarding PE of Foreign Tax Subjects on April 1, 2019. The aforementioned regulations can only be applied to foreign tax subjects not residents of Indonesia treaty country partners. Foreign tax 
subjects of residents of Indonesia treaty country partners cannot refer to the regulation as Lex Specialist derogate Lex Generalist treats Tax Treaty higher than the Domestic Tax Law. Tax Treaty regulates the avoidance of double taxation for Income Tax. Therefore, foreign tax subjects of residents of Indonesia treaty country partners cannot be subject to income tax based on the Tax Treaty. Excluding Tax Treaty to impose taxes on digital transactions income of foreign tax subjects will impose Indonesian unilateral taxes on residents of Indonesia treaty country partners. The exclusion violates the Indonesian Tax Treaty (Treaty Override). The government must take real steps and strategies in implementing the tax imposition on digital transactions, especially digital transactions made by foreign tax subjects of residents of Indonesia treaty country partners. These giant multinational companies acting as Indonesia treaty country partners have high tax potential.

\subsection{Review of International Tax Regulation Practices on E-Commerce Transactions}

The absence of a global consensus that regulates the international tax imposition for ecommerce transactions is an obstacle, making it difficult to impose taxes on foreign tax subjects, especially for countries that have e-commerce based companies as a source of income. Several other countries have taken unilateral steps to impose taxes on e-commerce transactions. These countries apply new tax rules to ensure that potential tax revenue on ecommerce transactions benefits the domicile and source countries.

\subsubsection{Asia}

In Southeast Asia, Singapore maintains neutrality between conventional and e-commerce business actors. Singapore does not make new tax regulations. Instead, Singapore uses and reviews existing regulations. Singapore issues an Income Tax Guide on E-commerce as a legal basis for the imposition of e-commerce taxes for the public and e-commerce entrepreneurs. On January 1, 2020, Singapore imposed a VAT on overseas digital goods and services. Malaysia has had a special division in handling e-commerce taxation since March 2009. This division creates a database on the e-commerce business and audits e-commerce businesses or companies. Similar to Singapore, Malaysia continues to use existing tax regulations as the basis for imposing e-commerce transactions. On April 1, 2015, the Malaysian government implemented the Goods and Service Tax to impose electronic taxes. The Goods and Service Tax requires each beneficiary to make tax deductions for business to business or customer to electronic customer payment [13]. On January 1, 2020, the Malaysian and Singaporean governments imposed a digital tax on digital services from foreign companies at a rate of $6 \%$. The imposition of tax rate applies to every foreign company with a turnover of more than RM 500,000 or equivalent to IDR 1.79 billion annually.

India applies taxes on digital transactions using the Equalization Levy Rules (EQL) scheme. Tax collection is carried out on foreign tax subjects receiving income from Domestic Tax Subjects at a rate of $6 \%$ of the gross value or transaction value. South Korea has implemented a digital tax and required overseas PE businesses to collect digital taxes on their customers. There is no fixed amount of tax collected by digital business actors. However, digital business actors are required to register with local tax authorities. In April 2014, Japan implemented a digital tax at $4 \%$ through an e-service consumption tax. 


\subsubsection{Europe}

The United Kingdom has enforced a significant economic presence by implementing the Diverted Profit Tax (DPT). The United Kingdom government levies a tax on profits or royalties from e-commerce companies that do not have a physical office or PE in their country at a 19\% rate. The United Kingdom enforced DPT from 2017 and a 2\% tax of the transaction value for digital taxes. France has imposed the Digital Service Tax at a rate of $3 \%$ of the transaction value. Italy, Spain, and France have all applied the Digital Service Tax at 3\%. Austria has applied a Digital Service Tax with a rate of 5\%.

\subsubsection{Australia}

In July 2017, the Australian government implemented the Good and Service Tax (GST) at $10 \%$ [29]. Australian government implemented GTS following Organisation for Economic Co-operation and Development (OECD) recommendations. Electronic services or activities subject to digital taxes refer to storage services (cloud), streamed or downloaded music, movies, applications, games, e-books, to online professional services. Australia obtained digital tax revenue of AUD 728 million in the first two years and achieved a GST original target of AUD 348 million in the first year.

\subsubsection{Africa}

South Africa has applied a digital tax and raised about USD 210 million. South Africa implemented the OECD recommendation to impose digital taxes on the sale of online services and products.

\subsection{Income Tax and Value Added Tax on E-commerce Transactions}

\subsubsection{Law Number 42 of 2009 (Value Added Tax Law) and its Derivatives}

VAT is the indirect tax levied on the sale and purchased transaction or delivery of Taxable Goods (TG) or Taxable Services (TS) carried out by Taxable Entrepreneurs (individual or entity taxpayers). VAT may be levied many times each time value is added and credited. The legal basis for VAT is Law Number 42 of 2009. E-commerce taxes are carried out similarly to the conventional transaction following Law Number 42 of 2009 Article 11 verse (1). VAT collection adheres to the accrual principle. Customs duty on e-commerce transactions is levied when taxable services are delivered and consumed within customs. Tax payable is incurred when the beneficiary uses taxable services - tax payable occurs when the beneficiary consumes intangible TG and TS. Therefore, several parties are delivering intangible TG and TS outside the customs to avoid Taxable Entrepreneur. Tax payable occurs at the time of consumption instead of the time of delivery. However, tax payable may occur at the time of payment if payment is received before the delivery or consumption outside custom. It is necessary to compare the date and time of payment, delivery, and utilization to determine TG and TS tax payable. Law Number 36 of 2008 regulates tax imposition on tax subjects based on income received or earned in the tax year. Therefore, tax subjects will be imposed after receiving income.

In the introduction, we have presented the complexity of e-commerce transactions and the obstacles of tax imposition on e-commerce transactions - the Indonesian government 
endeavors to make policies that accommodate potential taxes on e-commerce transactions and optimize tax revenue. The legal basis and regulation of e-commerce taxes aim to create fair regulation for conventional and online business actors. Conventional and business actors have the same tax obligations [32]. The government's failure to collect taxes on e-commerce transactions causes unbalanced competition between conventional and online entrepreneurs due to uneven tax burdens. Therefore, the government obtains non-optimal state revenue. The government has optimized tax revenues from e-commerce transactions through various tax regulations. The following is the dynamics of the taxation policy on e-commerce transactions applied in Indonesia. The Indonesian government's first policy was SE-62/PJ/2013, which regulates Income Tax and VAT on e-commerce transactions. Based on SE-62/PJ/2013, there are no new types of taxes on e-commerce transactions.

There is no differing tax imposition and tax regulations between e-commerce transactions and conventional transactions [33]. In 2015, the Indonesian government issued SE$06 / \mathrm{PJ} / 2015$, which states that the tax imposition of e-commerce and conventional transactions has the same tax administration provisions. In 2015, the Indonesian Government issued a regulation on the e-commerce roadmap Economic Policy XIV 2016. The policy applied a 1\% tariff for e-commerce business actors who are just starting their business. In 2018, the Minister of Finance issued Minister of Finance Regulation 210/PMK.010/2018. However, technology and business development allow foreign tax subjects to obtain large income from e-Indonesian commerce transactions. Therefore, it is necessary to formulate a tax policy that regulates ecommerce clearly and unequivocally to optimize tax revenue on e-commerce transactions.

\subsubsection{Expanded Definition of Permanent Establishment - Significant Economic Presence}

The three principles that form the basis of tax collection are: (1) the Residence Principle (domicile), the state has the right to impose taxes on taxpayers who reside in their country, (2) the Source Principle, the state has the right to impose taxes on taxpayers' income originating from their country, (3) the Nationality Principle, the tax imposition is related to the national status of the taxpayer. Members of OECD recommend applying significant economic presence to establish a PE for digital-based Multinational Companies (MNCs) in a country's economic activities. Law Number 11 of 2020 concerning Job Creation regulates the imposition of taxes for companies engaged in the digital economy (Over the Top). The policy regulates the imposition of taxes on digital business actors and deters tax avoidance. The government has expanded the definition of PE for digital business actors in Indonesia through Law Number 11 of 2020. Therefore, the tax imposition on digital business actors and PE have a definite and clear legal basis. Then, the tax imposition on e-commerce transactions of foreign business actors will refer to significant economic presence instead of physical condition. If a company makes profits in Indonesia, then the company is said to have a physical presence and PE in Indonesia. Therefore, the Indonesian government has the right to impose a tax on its digital business income.

Government Regulation Number 80 of 2019 Article 7 on Electronic Trading System (ETS) states that foreign companies engaged in the digital sector that have received benefits from the Indonesian public or consumers who have met certain criteria are considered to have met physical presence criteria in Indonesia. The criteria referred to the number of transactions, deliveries, and/or access. In 2020, the Indonesian government issued a Government Regulation in Lieu of Law Number 1 of 2020 to increase state revenue due to the declining economy. During the Covid-19 pandemic, only ETS business actors were capable of growing and prevailing. The Indonesian Government issued Government Regulation in Lieu of Law 
Number 1 of 2020 Article 4, 6, and 7 to respond to the Covid-19 pandemic - the Covid-19 pandemic limited community activities due to the need for social distancing. The pandemic, however, increased e-commerce transactions. The Indonesian government amended the regulation into Law Number 02 of 2020.

Law Number 2 of 2020 regulates taxes on digital or e-commerce business actors that do not have permanent business entities. The Indonesian government imposed tax based on significant economic presence criteria. Law Number 02 of 2020 Article 6 states that foreign traders, foreign service providers, and/or overseas Electronic System Trading Operators (ETSO) who meet the provisions for significant economic presence may be treated as PE. These parties are subject to tax if they meet the criteria for significant economic presence based on the consolidated gross turnover of business groups, sales, and active digital media users in Indonesia. In cases where Law Number 02 of 2020 Article 6 cannot be implemented due to agreements with other countries, namely the Double Taxation Avoidance Agreement, e-commerce with significant economic presence will be subject to Electronic Transaction Tax (ETT). The ETT mechanism is not contained in the Double Taxation Avoidance Agreement and is different from the imposition of income tax. ETT is a tax imposed on sales transactions of goods or services from outside Indonesia through the ETS mechanism. Foreign tax subjects carry out ETT or foreign ETS. Regulation of the Minister of Finance 48/PMK.03/2020 regulates ETT procedures for payment and income tax reporting.

The Indonesian government has issued a derivative regulation regarding ETS, namely the Minister of Finance Regulation 48/PMK.03/2020. The Ministry of Finance considers ETS as a source of revenue. VAT refers to the utilization of intangible TG and/or TE from outside the customs area. Appointed ETS business actors collecte, deposit, and report VAT to the Director-General of Taxes. ETS business actors are individuals or entities that carry out business activities in the ETS sector. The tariff charged is $10 \%$ of the value paid by goods and/or service beneficiaries. ETS business actors are foreign traders, overseas service providers, overseas ETS operators, and/or domestic ETS operators. ETS operators is a business actor that provides electronic communication facilities used for digital trade transactions (e-commerce).

\subsubsection{Regulation to Strengthen Tax Collection on E-Commerce Transactions}

After issuing Minister of Finance Regulation 48/PMK.03/2020, the government designated foreign companies as digital VAT collectors. In July 2020, the government designated six foreign companies as digital VAT collectors. These foreign companies started collecting digital VAT on August 1, 2020. The appointed foreign companies were Amazon Web Services Inc., Google Asia Pacific Pte. Ltd, Google Ireland Ltd., Google LLC, Netflix International B.V., and Spotify AB. In August 2020, the Directorate General of Taxes appointed ten international companies to collect digital VAT. These international companies started collecting digital VAT on September 1, 2020. The appointed international companies were Facebook Ireland Ltd., Facebook Payments International Ltd., Facebook Technologies International Ltd., Amazon.com Services LLC, Audible Inc., Alexa Internet, Audible Ltd., Apple Distribution International Ltd., Tiktok Pte. Ltd., and the Walt Disney Company (Southeast Asia) Pte. Ltd. The Indonesian Government appointed 12 e-commerce companies to collect digital VAT on goods and services consumed by Indonesian users. The e-commerce companies started collecting digital VAT on October 1, 2020. The appointed e-commerce companies were LinkedIn Singapore Pte. Ltd., McAfee Ireland Ltd., Microsoft Ireland Operations Ltd., Mojang AB, Novi Digital Entertainment Pte. Ltd., PCCW Vuclip (Singapore) 
Pte. Ltd., Skype Communications SARL, Twitter Asia Pacific Pte. Ltd., Twitter International Company, Zoom Video Communications Inc., PT Jingdong Indonesia Pertama, and PT Shopee International Indonesia.

Furthermore, the Directorate General of Taxes appointed eight companies as digital VAT collectors. The companies started collecting digital VAT on November 1, 2020, including Alibaba Cloud (Singapore) Pte Ltd., GitHub Inc., Microsoft Corporation, Microsoft Regional Sales Pte. Ltd., UCWeb Singapore Pte. Ltd., To The New Pte. Ltd., Coda Payments Pte. Ltd., and Nexmo Inc. Lastly, the Directorate General of Taxes appointed ten companies as digital VAT collectors effective from December 1, 2020. The companies were Cleverbridge AG Corporation, Hewlett-Packard Enterprise USA, Softlayer Dutch Holdings B.V. (IBM), PT Bukalapak.com, PT Ecart Webportal Indonesia (Lazada), PT Fashion Eservices Indonesia (Zalora), PT Tokopedia, PT Global Digital Niaga (Blibli.com), Valve Corporation (Steam), and beIN Sports Asia Pte Limited. The government endeavors to optimize tax imposition on Income Tax and VAT and increase state revenue. The government-appointed companies as digital VAT collectors as an attempt to create fair regulation between conventional and online business actors. Furthermore, the government needs to evaluate e-commerce clusters to ensure tax compliance and deter tax avoidance.

\section{Conclusions}

The Indonesian government has endeavored to utilize the growth of the digital economy by imposing taxes on e-commerce transactions. The government has issued clear and explicit tax regulations on e-commerce transactions to create fair regulation for conventional and online businesses in Indonesia. There is no differing tax imposition between conventional and online transactions.

The government implemented significant economic presence in new regulations to impose taxes on e-commerce transactions of foreign tax subjects. Furthermore, the government issued ETT to impose taxes on foreign tax subjects of residents of Indonesia treaty country partners at the same time. ETT aims to avoid Treaty Override and impose a tax on e-commerce transactions of foreign tax subjects.

In addition, the government has appointed companies as digital VAT collectors to strengthen tax collection on e-commerce transactions. The government needs to evaluate ecommerce clusters to ensure tax compliance and deter tax avoidance. The result of this research may provide clear information on tax regulation on e-commerce transactions. The ecommerce business actor may apply the content of this research to increase tax compliance and state revenue.

\section{References}

[1] C. I. Burhanuddin and M. N. Abdi, "Ancaman Krisis Ekonomi Global Dari Dampak Penyebaran Virus Corona (COVID-19)," Krisis, Ancaman Glob. Ekon. Dampak, Dari, vol. 17, pp. 710-718, 2020.

[2] S. Kemp, “Digital 2021: Indonesia.” Data Reportal, p. 103, 2021.

[3] D. K. Gangeshwer, "E-Commerce or Internet Marketing: A Business Review from Indian Context," Int. J. u- e-Serv. Sci. Technol., vol. 6, no. 6, pp. 187-194, 2013, doi: 10.14257/ijunesst.2013.6.6.17. 
[4] P. D. Dirgantari, Y. M. Hidayat, M. H. Mahphoth, and R. Nugraheni, "Level of use and satisfaction of e-commerce customers in covid-19 pandemic period: An information system success model (issm) approach,” Indones. J. Sci. Technol., vol. 5, no. 2, pp. 261-270, 2020, doi: 10.17509/ijost.v5i2.24617.

[5] M. R. Fedorko, "The current status and importance of e-commerce in a global perspective,” Online) J., vol. 4509, pp. 1339-4509, 2014, [Online]. Available: http://www.exclusiveejournal.sk.

[6] A. R. Abdu'a and S. Wasiyanti, "Pengukuran Kualitas E-Commerce Shopee Terhadap Kepuasan Pengguna Menggunakan Metode Webqual 4.0," Paradig. - J. Komput. dan Inform., vol. 21, no. 2, pp. 143-148, 2019, doi: 10.31294/p.v21i2.6357.

[7] M. Golovko, "E-Commerce: Concept and Legal Regulation In Modern Economic Conditions," J. Leg. Ethical Regul. Issues, vol. 22, no. 2, 2019.

[8] A. Lawal and R. C. Ogbu, "E-Commerce , Problems and Prospect in Nigeria," Intern. J. Sci. Eng. Appl. Sci., vol. 1, no. 3, pp. 230-236, 2015.

[9] Sirclo, "Menilik Tren Perkembangan E-Commerce Indonesia di 2020," Sirlo.Com. Sirclo, 2020.

[10] H. Nurhayati and Wolff, "E-commerce in Indonesia - Statistics \& Facts." Statista, 2021.

[11] A. S. Mulya and S. V. Agatha, "Apakah Pajak Pertambahan Nilai atas E-Commerce dapat diterapkan di Indonesia,” J. Account. Sci. Technol., vol. 1, pp. 26-38, 2020.

[12] Y. W. Widianto and L. S. Puspita, "Evaluasi Dampak Pengenaan Pajak Pertambahan Nilai pada Perdagangan Melalui Sistem Elektronik," Bappenas Work. Pap., vol. 3, no. 2, pp. 109-125, 2020, doi: 10.47266/bwp.v3i2.76.

[13] N. W. Sakti, Buku Pintar Pajak E-Commerce. Jakarta: VisiMedia Pustaka, 2014.

[14] R. P. Sari, "Kebijakan perpajakan atas transaksi e-commerce," Akuntabel, vol. 15, no. 1, p. 67, 2018, doi: 10.29264/jakt.v15i1.2889.

[15] Perppu No 1 Tahun 2020, “Tentang Kebijakan Keuangan Negara dan Stabilitas Sistem Keuangan Untuk Penanganan Pandemi Covid-19 dan/atau Dalam Rangka Menghadapi Ancaman Yang Membahayakan Perekonomian Nasional dan/atau Stabilitas Sistem Keuangan.” Pemerintah Republik Indonesia, Jakarta, p. 46, 2020.

[16] UU No. 2 Tahun 2020, “Tentang Penetapan Peraturan Pemerintah Pengganti UndangUndang Nomor 1 Tahun 2020 Tentang Kebijakan Keuangan Negara dan Stabilitas Sistem Keuangan Untuk Penanganan Pandemi Corona Virus Disease 2019 (COVID19) dan/atau Dalam Rangka Menghadapi Ancaman yang.” Jakarta, p. 53, 2020.

[17] PMK 48/PMK.03/2020, "Tentang Tata Cara Penunjukan Pemungut, Pemungutan, Dan Penyetoran, Serta Pelaporan Pajak Pertambahan Nilai Atas Pemanfaatan Barang Kena Pajak Tidak Berwujud Dan/Atau Jasa Kena Pajak Dari Luar Daerah Pabean Di Dalam Daerah Pabean Melalui Perdagangan Melalu.” Menteri Keuangan Republik Indonesia, Jakarta, 2020.

[18] C. N. Lomanto and Y. Mangoting, "Perlakuan PPN atas Transaksi E-Commerce," Tax Accouting Rev., vol. 3, no. 2, 2013.

[19] M. Raharjo, "Studi Kasus Dalam Penelitian Kualitatif: Konsep dan Prosedurnya." Universitas Islam Negeri Maulana Malik Ibrahim Malang, 2017.

[20] V. W. Sujarweni, Metodologi Penelitian. Yogyakarta: Pustakabarupress, 2014.

[21] S. Shahriari, S. Mohammadreza, and S. Gheiji, "E-Commerce and It Impacts on Global Trend and Market," Int. J. Res. -Granthaalayah, vol. 3, no. 4, pp. 49-55, 2015, doi: 10.29121/granthaalayah.v3.i4.2015.3022.

[22] E. M. Utomo, "Transaksi E-Commerce Sebagai Potensi Penerimaan Pajak di 
Indonesia," J. Akunt. Akunesa, vol. 2, 2013.

[23] A. Gupta, "E-Commerce: Role of E-Commerce in Today's Business," Int. J. Comput. Corp. Res., vol. 4, no. 1, 2014.

[24] C. K. Laudon and P. J. Laudon, Management information systems: managing the digital firm, vol. 7, no. 1. Pearson, 2015.

[25] K. C. Laudon and C. G. Traver, E-commerce 2016, Twelfth Ed. Pearson, 2017.

[26] SE-62/PJ/2013, "Tentang Penegasan Ketentuan Perpajakan Atas Transaksi ECommerce.” Direktur Jenderal Pajak, Jakarta, 2013.

[27] SE-04/PJ/2017, “Tentang Penentuan Bentuk Usaha Tetap bagi Subjek Pajak Luar Negeri yang Menyediakan Layanan Aplikasi dan/atau Layanan Konten melalui Internet.” Direktur Jenderal Pajak, Jakarta, pp. 1-5, 2017.

[28] PMK 35/PMK.03/2019, "Tentang Penentuan Bentuk Usaha Tetap. Semua peraturan di atas hanya bisa diterapkan pada Subjek Pajak Luar Negeri." Menteri Keuangan Republik Indonesia, Jakarta, 2019.

[29] J. R. Faifitasari, "Analisis Pajak Penghasilan Pemotongan Dan Pemungutan Atas Spotify Ditinjau Dari Teori Economic Presence,” vol. 4, no. No 2, pp. 44-51, 2020.

[30] UU No. 42 Tahun 2009, “Tentang Perubahan Ketiga Atas Undang-Undang Nomor 8 Tahun 1983 Tentang Pajak Pertambahan Nilai Barang Dan Jasa Dan Pajak Penjualan Atas Barang Mewah," no. 1. Jakarta, 2009.

[31] UU No. 36 Tahun 2008, “Tentang Perubahan Keempat Atas Undang-Undang Nomor 7 Tahun 1983 Tentang Pajak Penghasilan.” Jakarta, 2008.

[32] N. N. A. Paramitari, I. A. P. Widiawati, and L. P. Suryani, "Analisis Yuridis Pemungutan Pajak Dalam Transaksi E - Commerce di Indonesia,” J. Analog. Huk., vol. 1, no. 1, pp. 114-119, 2019.

[33] A. Cahyadini and I. Oka Margana, "Kebijakan Optimasi Pajak Penghasilan Dalam Kegiatan E-Commerce," Verit. Justitia, vol. 4, no. 2, pp. 358-387, 2018, doi: 10.25123/vej.3071.

[34] SE-06/PJ/2015, “Tentang Pemotongan dan/atau Pemungutan Pajak Penghasilan Atas Transaksi E-Commerce.” Direktur Jenderal Pajak, Jakarta, 2015.

[35] PMK 210/PMK.010/2018, “Tentang Perlakuan Perpajakan Atas Transaksi Perdagangan Melalui Sistem Elektronik (E-Commerce).” Menteri Keuangan Republik Indonesia, Jakarta, 2018.

[36] PP No 80 Tahun 2019, “Tentang Perdagangan Melalui Sistem Elektronik.” Jakarta, p. $61,2019$. 